SlavVaria 1/2021. 181-190

DOI: $10.15170 /$ SV.1/2021.181

\author{
ЖУЖАННА КАЛАФАТИЧ \\ (Будапешт, Венгрия)
}

\title{
Травматический опыт сталинизма в романах Гузели Яхиной
}

Аннотация: В центре исследования стоит вопрос, как в романахбестселлерах молодой писательницы Гузели Яхиной отражаются российские коллективные травмы и травматический опыт XX века. Действие романов «Зулейха открывает глаза» и «Дети мои» происходит в послереволюционный период, в среде этнических групп, ставших жертвами сталинского террора. С одной стороны, в анализе рассматривается, как Яхина изображает колониализм советской империи, с другой - анализируется роль сказочных и мифологических моделей в интерпретации исторических событий.

Ключевые слова: травматическое письмо, мифологический роман, сказочные матрицы, «Зулейха открывает глаза», «Дети мои»

История России в XX веке насыщена травмирующими событиями, которые следовали одно за другим стремительной чередой, наслаиваясь друг на друга: потери и травмы революции и гражданской войны, десятилетия сталинского террора, мировых войн, распада и развала советской империи. Едва хватило времени, чтобы взглянуть в лицо проблемам и прошлому, оценить последствия террора, растянувшегося во времени и охватившего несколько поколений, оплакать жертвы и разобраться с непереработанной памятью о них, как социальная, властная и экономическая перестройка постсоветского периода нанесла новые раны. Существует ряд причин, которые затрудняют попытки примириться с историческими потерями, посмотреть в лицо сталинизму, узнать о том, что произошло, оплакать жертвы и наказать виновных. Одна из них - это большое количество жертв (каждая четвертая российская семья пострадала от террора) и сложная ситуация, когда спустя месяцы преступники, сметенные очередной волной террора, сами становились жертвами (ЭТКИНД 2013). Пластичность, размытость границы, разделяющей жертву и преступника, саморазрушительный характер советского террора затрудняют как познание, рациональное (философское, историческое) понимание террора, так и выявление и привлечение виновных к ответственности. Жертвы советского режима практически не получили возмещения ущерба, а оставшиеся в живых «палачи» жертв не были привлечены к ответственности ни на институциональном, ни на индивидуальном уровне. Несмотря на 
публикацию свидетельств очевидцев, мемуаров и разоблачительных романов об истории ГУЛАГа, преследованиях и репрессиях, которым подвергались люди в советское время, а также частичную доступность архивных материалов, не развернулось значительных политических, философских или социальных дебатов по оценке преступлений коммунистического режима. Отсутствие политического и морального суждения породило множество существенно различных интерпретаций прошлого, включая ностальгию по сталинизму (ЭТКИНД 2004: 59).

Пространством для осмысления и проблематизации травматического опыта очень часто является создание художественной литературы. Превращение травматического события в повествование, исследование смысла потери создает возможность для проигрывания ощущения боли в сообществе, для работы с горем. В русской литературе XXI века появились различные варианты травматического письма. Один из них - магический историзм $^{1}$ (термин А. Эткинда), в котором доминирует магическое мышление, то есть исторические события интерпретируются в соответствии с особыми фантазиями. В произведениях Виктора Пелевина и Владимира Сорокина часто встречаются странные, необычные и пугающие существа (люди-насекомые, вампиры, волки-оборотни, лисы). Поэтика странности четко связана с символизацией невысказанных травм советской эпохи (ЛИПОВЕЦКИЙ, ЭТКИНД 2008: 175). Однако с 2010-х годов наблюдается возврат к реалистичному изображению событий советской истории, вплетение тем гражданской войны, раскулачивания, этнических чисток и лагерей в мир романов. В этих текстах исследование событий, таблоидная обработка и оценка исторических фактов, эпическое изображение разнообразных человеческих судеб и поведения больше не являются главной задачей. История присутствует как фон для повествования истории жизни центральной фигуры или семьи, и ее интерпретация, соответственно, субъективна. Это относится и к роману Захара Прилепина «Обитель» (2014), и к произведению Евгения Водолазкина «Авиатор» (2016). Бестселлеры молодой писательницы Гузели Яхиной - «Зулейха открывает глаза» и «Дети мои» - также вписываются в этот ряд. Действие обоих романов происходит в послереволюционный период, в среде этнических групп, ставших жертвами сталинского террора. В обоих случаях Яхина опиралась на личный опыт близких родственников: ее бабушка была татаркой, пережившей раскулачивание и сибирскую депортацию, а ее дед был учителем немецкого языка. Кроме того, будучи филологом, писательница, естественно, исследовала архивы, используя исторические и этнографические работы наряду с мемуарами выживших. В обоих романах упоминается ряд исторических событий (включая гражданскую войну, принудительную коллективизацию и раскулачивание, великий голод, создание трудовых лагерей, сталинские

${ }^{1}$ Подробнее об этом см. ЭТКИНД 2016. 
чистки), но они не находят прямой интерпретации и оценки в повествовании. Гораздо важнее представить перспективу маленького человека, уязвимого в потоке исторических событий, искать поддерживающую силу даже в катаклизмах. В несколько идеалистическом, мелодраматическом мире $^{2}$ Яхиной эта сила - любовь и обращение друг к другу. Не случайно, что сказочные мотивы играют важную роль в структуре сюжета обоих произведений. Несмотря на традиционное сюжетосложение и повествование, ни «Зулейха открывает глаза», ни «Дети мои» не являются однородными по жанру текстами: помимо этнографических описаний, реалистических элементов, поворотов, характерных для воспитательного и приключенческого романа, и мелодраматической нити, в обоих произведениях наблюдаются черты мифологического романа и структура волшебной сказки.

Действие романа «Зулейха открывает глаза», опубликованного в 2015 году, происходит в 1930-е годы. Главная героиня - добросердечная 30летняя татарка Зулейха Валиева, которая вопреки всему находит себя, свою внутреннюю свободу и любовь в трудовом лагере под Ангарой в Сибири. Зулейха живет в поселке Юлбаш с властной, вечно унижающей ее слепой свекровью и холодным мужем Муртазой, который старше ее на 25 лет. Зулейха находится в их власти, ее мир ограничен и управляется традицией. Помимо того, что ее не любят, ее положение усугубляется тем, что ни одна из четырех ее дочерей не выжила. Она переносится из закрытого мира татарской деревни и семьи в другой, жестокий мир после того, как была выселена как кулачка. Чекист Игнатов, который без внутренних сомнений проводит насильственную коллективизацию, убивает ее непокорного мужа, собранных кулаков перевозят в Казань, а затем вместе с питерскими интеллигентами, врагами народа и обычными преступниками их отправляют в вагонах для скота в Сибирь. Поезд, пересекающий практически всю огромную страну, в сгущенном и обостренном виде показывает характер советского террора, поскольку депортируемые - это люди разных религий, национальностей и профессий, наказанные по разным причинам и под разными лозунгами. Пережившие ужасы поездки, включая затопление баржи, создают новую жизнь из ничего на берегах Ангары, основывая деревню. Они как новые робинзоны ${ }^{3}$ преодолевают природные трудности, холод и голод, а также тяжелую работу по заготовке леса. Именно в этой суровой обстановке

\footnotetext{
${ }^{2}$ Марк Липовецкий даже считает, что Яхина намеренно скрещивает соцреалистический роман с бразильской мыльной оперой (ЛИПОВЕЦКИЙ 2016: URL).

${ }^{3}$ Жанр робинзонады прослеживается в нескольких романах, действие которых происходит в условиях советского лагеря, среди ссыльных и перемещенных лиц. Например, «Ложится мгла на старые ступени» А. Чудакова (2001) и «Авиатор» Водолазкина (2016).
} 
Зулейха рожает своего сына Юзуфа, зачатого до смерти мужа. Чтобы сохранить его жизнь в условиях лагеря, она готова принести себя в жертву и питает младенца собственной кровью. Выжить и вырастить ребенка Зулейхе помогают многие люди, в том числе Лейбе, врач немецкого происхождения, и Игнатов, начальник лагеря, с которым она пережила любовь. Сам большевик Игнатов - пленник и жертва сталинского режима, он не может покинуть поселок, а позже его лишают командного звания.

Метафорический смысл названия романа ${ }^{4}$ легко уловим: женщина, ранее подавленная, почти не ориентировавшаяся во внешнем мире, редко называемая по имени, говорившая о себе в третьем лице, становится независимой, способной защитить себя и своего сына личностью, преодолевающей условности и запреты своей религии. Ее отношения с Игнатовым пересекают, нарушают множество границ, ведь он русский, коммунист, атеист и убийца ее мужа. В то время как любовь является причиной нарушения нормы, становление себя, пробуждение самосознания связано с оПытом материнства (МОТЕЮНАЙТЕ 2019: 290). Именно материнство и повышенная потребность в уходе и заботе заставляют Зулейху понять поведение свекрови, мифологизированная фигура которой сопровождает ее всю жизнь. Зулейха также воспитывает своего сына в духе защиты. Юзуф в мире лагеря имеет возможность ознакомиться с разными культурами. Зулейха знакомит его с татарской народной культурой, верованиями и легендами, рассказывает ему сказки, в том числе сказку о поисках шах-птицы Семруга, в которой дается аллегорическое толкование событий и истории. Эта мудрая птица чарующей и блистательной красоты живет на самой высокой горе в мире, куда птицы отправляются после ссоры, чтобы Семруг восстановил справедливость среди них. Их трудный путь от подножия горы ведет через 7 долин - Долину Исканий, Любви, Познания, Безразличия, Единения, Смешений и Отрешения. Каждая из этих долин - это испытание для птиц, и если они не смогут его выдержать, если они недостаточно решительны, если их мучает неразделенная любовь, их ум не пытлив, они не открыты для новых идей, если они не могут уравновесить различные чувства в своем сердце, если они считают проделанный путь бесполезным, они погибают. Только 30 птиц добираются до чертогов Семруга. Это число совпадает с числом выселенных лиц, переживших долгое путешествие, полное страданий, а затем создавших поселение Семрук. «Глаза их сомкнулись от наполнившего мир яркого света, а когда раскрылись - узрели лишь друг друга. В этот миг они постигли суть: они все и есть Семруг. И каждая по отдель-

\footnotetext{
${ }^{4}$ См. «Очень удачное название книги „Зулейха открывает глаза” запечатлевает не только внутреннее состояние героини, но и основной внутренний жест этой прозы. Зулейха открывает глаза на мир, который, хорош он или (что случается в ее судьбе чаще) до невыносимости плох, предстает новым, прозрачным, ясным и каким-то умытым» (АБАШЕВА, АБАШЕВ 2016: URL).
} 
ности, и все вместе.» (ЯХИНА 2016: 402). «Идея божества, которое живет между людьми и выражает себя в единении и тяге людей друг к другу» (САВКИНА, РОЗЕНХОЛЬМ 2016: 24) в интерпретации Савкиной и Розенхольма перекликается с социалистическим мифом и указывает на архетипическую, древнюю природу идеи социализма. Но я считаю, что это скорее метафорически указывает на то, что ни один из принципов, ни принцип общности, ни принцип индивидуальности, не может принести примирение и успокоение. Эта мысль прослеживается и в заказанной в агитационных целях фреске носящего говорящее имя художника, Иконникова. Картина описана в главе «Четыре ангела» : «А там небесный свод: прозрачная синева, по которой легко, перьями, плывут облака. Четыре человека вырастают из четырех углов потолка, напряженно тянут руки вверх, словно стараясь дотянуться до чего-то в центре [...] Златовласый врач в крахмально-белом халате, атлетический воин с винтовкой за спиной, агроном со связкой пшеницы и землемером на плече, мать с младенцем на руках - они молоды и сильны; лица - открыты, смелы и чрезвычайно напряжены, в них одно стремление - дотянуться до цели. До какой? В центре потолка - пустота» (ЯХИНА 2016: 421-422). Позже Иконников заполняет это пустое пространство красным флагом и интерпретирует свою потолочную фреску в социалистическом духе для необразованного руководства. Но помимо пропагандистского прочтения, он также раскрывает другую интерпретацию своему талантливому ученику Юзуфу, который внимательно следит за творческим процессом: фигуры тянутся не к трансцендентному, а друг к другу. Все четверо легко узнаваемы в мире романа, и Юзуф узнает в них черты близких ему людей ${ }^{5}$. Лейбе, Игнатов, Зулейха и Сумлинский принадлежат к разным культурным средам, но их объединяет стремление друг к другу. Дружба, уважение к другим, сотрудничество, любовь и надежда - вот те ценности, которые в сказочном мире Яхиной противостоят террору, жестокости и страданиям, и делают жизнь сносной, а существование пригодным для жизни.

Роман Яхиной «Дети мои», опубликованный в 2018 году, можно рассматривать как продолжение предыдущего произведения, поскольку в нем тоже переплетаются исторические факты с мифологическими элементами и сказочными сюжетами. Однако мифологический, фантастический план теперь занимает центральное место, кроме того, этот роман гораздо богаче и сложнее в плане образности и стиля. Происходящее в начале прошлого века, в основном в послереволюционный период, действие также разворачивается в замкнутом, почти не имеющем контактов с внешним миром сообществе, в Гнадентале, (вымышленном) поселении

\footnotetext{
${ }^{5}$ Нетрудно заметить параллель между Иконниковым и паном Аполеком. Странствующий художник Бабеля на заказной картине также создавал лики святых по образцу простых сельских жителей.
} 
немецкой колонии на Волге. Немецких колонистов, приехавших в Россию, Екатерина II называла своими детьми - это обращение вынесено в название романа. В то же время название отсылает к отношениям между родителями и детьми, к смене поколений. Согласно архетипической схеме, поколение детей восстает против отцов. Так происходит с Кларой Гримм. Она, когда отец хочет увезти ее в Германию и там выдать замуж, убегает от него в дороге и укрывается у главного героя произведения, Якоба Баха. Бах - школьный учитель, типичный маленький человек, распорядок дня которого подчиняется привычному расписанию, его жизнь, соответственно, предсказуема. Переломный момент в его жизни наступает, когда Клара становится его ученицей. Но они не могут иметь прямого контакта друг с другом, ведь по приказу отца, Удо Гримма, их разделяет ширма. Во второй раз мир Баха переворачивается с ног на голову, когда девушка, которую он никогда раньше не видел, появляется у него после побега от отца, ожидая любви и счастья от Баха. Не в силах смириться с этим, члены колонии отвергают пару, поэтому они возвращаются в заброшенный, труднодоступный отцовский хутор. То, что это место является заколдованным, мистическим, стало ясно уже во время первого путешествия Якоба и его наблюдений. Хутор появляется перед путешественником почти из ниоткуда, его даже не видно с реки. Время здесь не течет обычным образом, границы различных пространств также постоянно меняются, становясь все более подвижными. Хутор - это заколдованное место, откуда никто не может уйти по своей воле, на самом деле является тюрьмой. Но здесь, чудесным образом, всегда есть что поесть, из-за чего в определенные моменты он кажется раем на земле, убежищем от бренного мира. Здесь влюбленные переживают гражданскую войну, здесь Клара рожает дочь, которая не является биологическим ребенком Якоба. Физические отношения Баха и Клары оказываются бесплодными, а женщину, жаждущую ребенка, насилуют и делают матерью вторгшиеся на хутор разбойники. Она умирает при родах. Потеря Клары становится новым потрясением для Якоба, который после пережитого испытания и травмы полностью отворачивается от мира и больше не хочет и не может говорить.

Он пытается сохранить жизнь ребенка в тишине и примирении, взаимодействуя с внешним миром только ради малютки. В своем календаре он фиксирует свои наблюдения и переживания, следы насильственных социальных и экономических преобразований наблюдаются и в метафорических названиях годов: например Год Разоренных Домов, Год Голодных, Год Мертвых Детей, Год Большой Лжи, Год Большого Голода, а также период террора между 35 и 38 годами - Годы Вечного Ноября. Большинство исторических событий зависит от одного человека, вождя. Сталин, хотя он нигде не назван, является одним из персонажей романа, и четыре из 30 глав романа направлены на то, чтобы осветить фигуру и точку зрения Сталина. Эти главы дают автору 
возможность представить историю немецкой колонии в Поволжье (включая создание АССР Немцев Поволжья, коллективизацию, раскулачивание, а затем упразднение автономной республики, депортацию немцев) в фактологическом и документальном ключе. В то же время деятельность «отца народов», его решения о судьбе стран, народов и людей, все его «игры» представлены в сказочном ракурсе. Подобно Екатерине Второй и Удо Гримму, он кажется мифологическим существом, и чувствует себя великаном в мире простых людей, карликов. Он живет за высокими стенами Кремля, отдыхает в высоких горах Кавказа и осматривает Поволжье с самолета. Вид Волги приводит его в экстаз, он чувствует все реки сразу, и в этом катартическом опыте он ощущает величие страны и отождествляет себя с ней. «Он ощущал страну чутко и всеобъемлюще, как ощущают собственное тело, - каждый вершок земли, каждую меру воды и каждую копошащуюся на этой земле или в этой воде жизнь» (ЯХИНА 2018: 279). Но во сне он уже отделен от мира людей огромным расстоянием. Сидя на плечах безликих металлических гигантов, он может видеть землю лишь издалека, звук жертв гигантских шагов не достигает его. Сталина привлекала не только монументальность в пространстве, но и грандиозный масштаб различных операций, включая этнические чистки. Однако сцены с животными, связанные с его фигурой (кормление хищных рыб и казнь бродячих собак), не оставляют сомнений в том, что «отца народов» ждет та же участь, что и статую Екатерины Великой в Марксштадте: он будет свергнут своими детьми, восставшими против великанов и жаждущими перемен.

Сказки в романе навеяны немецкими народными сказками и романтическими произведениями. Авторская дидактическая практика именования делает присутствие немецкой литературы и культуры очевидным для всех читателей. Помимо Баха и Гримма, мы встречаем Вагнера, Генделя, Грасса, Брехта, Бёлля и Гофмана, приехавшего из Германии в Советский Союз строить коммунизм. Чтобы лучше узнать местных жителей, он собирает обычаи, особенно его интересуют пословицы, песни и сказки. За них он платит Баху едой. Придавая сказкам и рассказам Баха идеологическую окраску, он отправляет их в газету под псевдонимом. Бах верит, что его сказки обладают магической силой, что они способны влиять на реальность, и таким образом он хочет помочь жителям колонии, но спустя некоторое время не может остановить превращение в реальность рассказов, содержащих необычные, кровавые, трагические и гротескные элементы. Через сказочные матрицы раскрываются страдания (голод, смерть, разрушения, насилие), которые испытывали немцы, жившие вдоль Волги в советское время, однако рассказчика больше всего интересует душа Баха.

В центре романа, именно как и в произведении «Зулейха открывает глаза», находится родительская любовь. Бах боится за свою дочь и 
защищает ее, но любовь помогает ему преодолеть этот страх. ${ }^{6}$ Таким образом, он может позволить и своей дочери Анче, и приемному сыну Ваське Волгину покинуть отцовский дом, и при этом находит свое призвание. Он ремонтирует и перестраивает хутор, чтобы приютить потерявших свои семьи беспризорных детей, а потом отправляется на дно реки. Волга, которая играет роль во всех важных моментах сюжета, воплощает в себе все архетипические черты реки. Волга обрамляет историю, она соединяет и разъединяет, представляя и воплощая жизнь и смерть. Ее течение не зависит от событий человеческих жизней. В завершении романа Бах, как и Гофман, погружается в Волгу. Он, как Садко в царстве морского царя, остается живым и ощущает подводный мир, видит все, что поглотила река. В мифологическом пространстве Волги все предметы и существа сохраняют свою форму, поэтому Бах узнает Удо и Тильду, умерших, пропавших гнадентальцев, и встречает ставшее прекрасным в смерти тело Гофмана. Река хранит память в отличие от мира людей, в ней ничто не остается бесследным, ничто не исчезает навсегда. Во время путешествия в другой мир Бах теряет страх, которым была пронизана вся его эпоха, и, несмотря на то, что он является маленьким человеком (карликом), он способен отождествиться со стихией воды и воспринять бесконечность пространства изнутри. «Пальцы ног его несло в тихие заводи Шексны и Мологи, к пологим берегам Дубны и Костромы. Колени раскинулись по Оке, бедра легли в синие воды Свияги. Руки его дотянулись до Камы, распластались по изгибам Вятки, Чусовой и Вишеры. Туловище растеклось вдоль Жигулевских гор и Змеевых гор, по устьям Иргиза и Еруслана. Волосы - разметались по Ахтубе, концами макнувшись в Каспий. Бах растворялся в Волге.» (ЯХИНА 2018: 483). В этой точке пересекаются судьбы Сталина и Баха, великана и карлика, государственного деятеля и маленького человека. Только в то время, как вождь, усиливая страх по всей стране, сам становится все более и более боязливым и тревожным, шульмейстер обретает спокойствие, прочный внутренний мир и осознает свою задачу. Эпилог посвящен его памяти и памяти других карликов - жертв. Однако судьбы в романе завершаются в менее сказочном и мифологическом ключе, поскольку нарратор приближает судьбы и жизненные пути к реальности: он рассказывает об аресте и

\footnotetext{
6 Тюнде Сабо интерпретирует молчание Баха в контексте традиции Нового Завета. «Само название романа - наряду со ссылкой на обращение Екатерины II к немцам-колонистам XVIII века - является известной фразой из первого послания Иоанна, в котором отказ от слова отождествляется с деятельной любовью. „Дети мои! Станем любить не словом или языком, но делом и истиною” (1 Иоанна 3:18). Сверхзадачей героя романа Яхиной является именно освоить деятельную любовь и вместе с тем победить свой страх перед внешним миром.» (САБО 2021).
} 
смерти Баха, о браке Анны и Василия, об испытаниях депортированных немцев.

Яхина показывает колониализм советской империи, не идеализируя при этом угнетенное сообщество. Закрытые миры, порабощенные традициями, также калечат личность. Единственная надежда - на то, что люди обратятся друг к другу с любовью. Эта идея, знакомая по русской литературе (и слишком расхожая), в романах Яхиной видоизменяется. И, возможно, именно это возвышает ее над банальностью. Любовь рассматривается в обоих романах не только как защитная, поддерживающая сила. Важным компонентом этого чувства является умение отпускать любимого человека. Именно принцип личности отодвигается на задний план людьми, охваченными лихорадкой преследования великих социальных утопий, или группами, требующими приверженности традициям. Благодаря этой любви, которая не стремится завладеть другим человеком, Юзуф, сын Зулейхи, и дочь, и приемный сын Баха могут вырваться из замкнутого мира, следовать своим желаниям и реализовать себя. В какой степени они смогут воспользоваться предоставленной им возможностью, как они смогут реализовать свою личность в данном историческом контексте, во многом зависит только от них самих.

\section{Литература}

АБАШЕВА М., АБАШЕВ В. (2016) Книга как симптом. Как сделан роман Гузели Яхиной «Зулейха открывает глаза» // Новый Мир, 2016. №5. 177-182. https://magazines.gorky.media/novyi mi/2016/5/kniga-kak-simptom.html (Дата обращения: 02.06.2021)

ЛИПОВЕЦКИЙ М., ЭТКИНД А. (2008) Возвращение тритона. Советская катастрофа и постсоветский роман // Новое литературное обозрение, 2008. № 94. 174-196.

ЛИПОВЕЦКИЙ М. (2016) ЗаНос. Продолжение полемики вокруг «НОСа» - 2015: Марк Липовецкий отвечает Константину Богомолову. https://www.colta. ru/articles/literature/10136-zanos (Дата обращения: 01.06.2021)

МОТЕЮНАЙТЕ И. (2019) Травма советского лагеря в современном русском романе (Г. Яхина, Е. Водолазкин) // Знаковые имена современной русской литературы: Евгений Водолазкин. Краков, 2019. 283-295.

САБО Т. (2021) Феномен молчания в современной русской прозе (Романы Е. Водолазкина, Л. Улицкой и Г. Яхиной) // Acta Universitatis Lodziensis. Folia Litteraria Rossica, 2021. № 14. 231-245. DOI: 10.18778/1427-9681.14.20

САВКИНА И., РОЗЕНХОЛЬМ А. (2016) «Секрет ее успеха»: размышления о романе Гузель Яхиной «Зулейха открывает глаза» // Лабиринт, 2016. № 3-4. 22-25.

ЭТКИНД А. (2004) Время сравнивать камни. Постреволюционная культура политической скорби в постсоветской России // Ab Imperio, 2004. № 2. 33-76. DOI: $\underline{10.1353 / \mathrm{imp} .2004 .0040}$ 
ЭТКИНД А. (2013) Работа горя и утехи меланхолии // Неприкосновенный запас, 2013. № 3. https://magazines.gorky.media/nz/2013/3/rabota-gorya-i-utehimelanholii.html (Дата обращения: 03.06.2021). DOI: 10.1353/imp.2013.0083 ЭТКИНД А. (2016) Кривое зеркало. Память о непогребенных. Москва, 2016. ЯХИНА Г. Зулейха открывает глаза. Москва, 2016.

ЯХИНА Г. Дети мои. Москва, 2018.

The traumatic experience of stalinism in the novels of Guzel Yakhina. The focus of the study is on how the bestselling novels of the young writer Guzel Yakhina reflect on Russian collective trauma and the traumatic experience of the $20^{\text {th }}$ century. The novels Zuleikha and My Children are set in the post-revolutionary period, among ethnic groups who were victims of Stalinist terror. The analysis explores how Yakhina depicts the colonialism of the Soviet empire and the role of mythic and mythological models in the interpretation of historical events.

Keywords: traumatic writing, mythological novel, fairy-tale patterns, Zuleikha, My Children 